\title{
Ideologija, klasa i pitanje političke subjektivizacije u Bosni i Hercegovini
}

\author{
ASIM MUJKIĆ \\ Fakultet političkih nauka, Univerzitet u Sarajevu
}

\begin{abstract}
Sažetak
Autor propituje ulogu ideologije, mita i klase u razumijevanju kompleksnih procesa savremene političke subjektivizacije u BiH. Polazeći od revolucionarnog konteksta s početka devedesetih godina dvadesetog stoljeća koji razumijeva kao paralelni proces nacionalne i kapitalističke reaproprijacije, autor na pitanje pod kojim uslovima, diskurzivnim i institucionalnim, određene etničke razlike postaju politički relevantnima, postaju izvorom političke moći i mobilizacije, razvija odgovor u vidu antireprezentacionalističke hipoteze po kojoj su to s jedne strane diskurzivni i institucionalni uslovi "nacionalne države" shvaćene kao države homogenog etnonacionalnog domaćina i zanemarive etnonacionalne manjine, a s druge strane njima komplementarni diskurzivni i institucionalni uslovi kapitalističkog poretka iz kojega se nacionalni poredak historijski izdiže, a koji podrazumijeva klasnu strukturiranost. Subjekt proizvodnje nacionalno-kapitalističkog poretka je vladajuća klasa, u slučaju $\mathrm{BiH}$ klasa etnopolitičkih poduzetnika koja je u posjedu sredstava za proizvodnju društvenog života uopće: i materijalnog i onog simboličkog.

Ključne riječi: ideologija, mit, klasa, politička subjektivizacija, Bosna i Hercegovina
\end{abstract}

\section{Uvod: polazišna pitanja i perspektive}

Danas će se u javnom diskursu u BiH rijetko naići na osobu, a pogotovo na političku organizaciju koja će se deklarirati (etno)nacionalističkom. Ako uopće i prihvati razgovor o nacionalizmu, prosječni će građanin ove zemlje biti spreman da vam održi slovo o "dobrom" i "lošem" nacionalizmu, pri čemu je dobar nacionalizam obično izjednačavan s patriotizmom po kom se "voli svoje i poštuje tuđe", a loš nacionalizam je šovinizam koji nipodaštava tuđe i tako, u konačnici, uništava i svoje. Ta "prirodnost" i zdravorazumnost patriotskog stava u čijem je temelju uvjerenje 
o ne-nacionalizmu ili dobrom - "reaktivnom" nacionalizmu "svoje grupe" prije će biti, kako ću u tekstu koji slijedi pokušati pokazati, simptomom ideološke hegemonije etnonacionalizma nego njezinog odsustva. Ništa bolje nije ni s političkim organizacijama od kojih nijedna nema pridjev "nacionalistički" u svom imenu, niti su im partijski programi eksplicitno nacionalistički. Naprotiv. Tekstovi tih dokumenata odišu ljudskim pravima i slobodama, poštovanjem drugog i drugačijeg koje se referira na tipični repertoar liberalno-demokratskih vrijednosti kakav susrećemo u programskim dokumentima europskih partija, ali ipak, "zluradi jezici” ih stalno proglašavaju nacionalističkim. Kako možemo nekog pojedinca određivati kao etnonacionalistu, a političku stranku i njezinu demokratski izabranu vlast proglašavati etnonacionalističkom kada se oni tako nikada izravno ne izjašnjavaju? Zatim, je li etnonacionalistička ideologija, ako i postoji, samo puka strategija osvajanja i održavanja na vlasti ili je riječ o trajnijem opredjeljenju?

Paralelno s deklarativnim "ne-nacionalizmom" ili "dobrim nacionalizmom" kao patriotizmom gotovo da vlada konsenzus u javnosti oko toga da $\mathrm{u} \mathrm{BiH}$ i nema nikakve posebne ideologije, pa čak i da su politički vlastodršci valjda toliko "nazadni” ili "primitivni” da još nisu ni dosegli neki ozbiljniji stupanj ideologizacije. Iste stvari čut ćemo i o kapitalizmu. No je li javno odsustvo ideologije upravo simptom njezine sveobuhvatne naturaliziranosti, njezina prelaska u principe zdravog razuma, pa se zbog toga ona više uopće i ne može identificirati kao ideologija? $\mathrm{Ne}$ provodi li hegemonijska etnonacionalistička elita $\mathrm{BiH}$ u sve tri svoje podvarijante svojevrsnu strategiju "eksnominacije" (Barthes, 1991), odnosno "odbijanja svog imenovanja" podmećući u prvi plan apstraktnu odrednicu svoga naroda? Uostalom, ideologija kao legitimacijski narativ političke vladavine partikularne društvene grupe koji, s više ili manje uspjeha, odgovara na pitanje "kako iz gomile raznolikosti iskovati bilo kakvo kulturno i političko jedinstvo" (Malešević, 2017: 22) nikada se i ne percipira kao "tek" ideološka istina, već ili kao zdravorazumski stav ili pak kao znanstvena istina. O njezinoj ideologičnosti moći ćemo tek govoriti nakon analize toga što ljudi, nositelji vlasti i njihovi podanici rade u javnoj i političkoj sferi, načina na koji djeluju i koje posljedice proističu iz njihovog djelovanja te kako ona u obilju međuljudskih interakcija djeluje na nivou svakodnevnog življenja. Etnonacionalistička kao i svaka druga ideologija pokušat će se pozicionirati u međuprostoru, s jedne strane, društveno-historijskih okolnosti i, s druge strane, političkih ambicija kojima ona služi, odnosno kao odraz određenih grupnih interesa, ali i njene "sposobnosti da pobudi i vodi samo političko djelovanje i time oblikuje materijalni život" (Heywood, 2005: 2-3). Na tom tragu, ovaj tekst predstavlja pokušaj osvjetljenja fenomena ideologije etnonacionalizma u $\mathrm{BiH}$ i njezine dominacije, odnosno predstavlja "pokušaj imenovanja" onoga što ne samo izmiče svom imenovanju nego se i pogrešno predstavlja. Smatramo važnim razumjeti modele njezine svako- 
dnevne proizvodnje naročite vrste stvarnosti. U dodatku, smatramo iznimno važnim pokušati identificirati politički subjekt ili - ostanimo vjerni dejtonskom duhu - političke subjekte čije jedinstvo (i unutrašnje i međusobno) i hegemoniju ta ideologija osigurava.

Kako političkog subjekta koji izbjegava biti imenovan "istjerati na čistinu”? S obzirom da se moderna nacionalna država od svoga postanka u biti ozbiljuje kao vladavina moćne, utjecajne manjine - "buržujske klase" - nad suštinski razvlaštenom većinom - "proletarijatom", "mnoštvom" - utoliko je ta manjina jedini istinski "politički narod”. Buržoazija se, riječima Barthesa, "stapa s narodom" (Barthes, 1991) odstranjujući postupno ono što se ne "uklapa" u njezinu predodžbu o identitetu toga naroda, što općenito zovemo "drugim" (anarhisti, komunisti, homoseksualci, "inovjerci”" i slično). Vladavina manje klase nad državnim aparatom, njegovim mehanizmima i procedurama proizvodi svojim svakodnevnim djelovanjima određeni stupanj "klasne svijesti", političke subjektivnosti koji se artikulira i referira unutar sasvim određenog ideološkog sistema, a potom i reproducira uz pomoć ideoloških aparata.

Reći da neki politički subjekt nema ideologiju znači lišiti taj politički subjekt sistema političkih vjerovanja, lišiti ga plasiranja određenih "kognitivnih mapa" koje šire građanstvo upućuju na to kako da razumiju svijet i kako da se orijentiraju u njemu - u krajnjem, to znači lišiti ih svog političkog subjektiviteta. Osim toga, nisu li se sami subjekti političkog života u BiH “ideološki” opredijelili učlanjujući se formalno u europske ideološke grupacije "narodnjaka" i "socijalista"? Nije li na prvim višestranačkim izborima 1990. u BiH postojala jasna ideološka platforma nacionalnih stranaka izražena kao "antikomunizam", "građanska država", "ljudska i nacionalna prava"? Nadalje, nije li ideološko pozicioniranje političkih subjekata u $\mathrm{BiH}$ 1990. predstavljalo samo dio šireg historijsko-političkog transformiranja prostora istočne i jugoistočne Europe nakon Revolucije iz 1989. kada je, kako ističe Heywood, "kolaps komunizma rezultirao pojavom niza ideoloških snaga? Glavne su nacionalizam, posebno etnički nacionalizam koji je u mnogim postkomunističkim državama zamijenio marksizam-lenjinizam kao vodeću ideologiju" (Heywood, 2005: 21).

Uistinu, širom pobunjeničkog istoka Europe novouspostavljene predstavničke demokratije su "transformirane" u mehanizam vladavine i zaštite novih ekonomskih i etnopolitičkih elita. Demokratska tranzicija podrazumijevala je najprije $n a-$ cionalnu reaproprijaciju svoje države koja se odvijala paralelno s njenom kapitalističkom reaproprijacijom (kroz zaposjedanje institucija i ovladavanja procedurama raspolaganja javnom imovinom i resursima, a potom i kroz razne modele privatizacije). Taj proces demokratske tranzicije u istočnoj i jugoistočnoj Europi mogli bi- 
smo opisati riječima Rogersa Brubakera kao proces etnokulturne nacionalizacije ${ }^{1}$ koja se realizirala revolucionarnim putem kao revolucionarna aproprijacija ${ }^{2}$ svoje nacionalne države. Taj prevrat je uz manja ili veća komešanja proveden u monoetničkim nacionalnim državama ili u multietničkim socijalističkim federacijama u kojima su se etničke i republičko-administrativne granice poklapale, dok je u državama s većim stupnjem etničke izmiješanosti stanovništva doveo do etničkog konflikta, pa i krvoprolića, kao što je slučaj sa zemljama bivše Jugoslavije. Demokratska tranzicija kakva je bila na djelu tokom Baršunaste revolucije mora se onda shvaćati u ovom dvostrukom smislu - s jedne strane kao kapitalistička reaproprijacija koju je neizbježno pratila i etnonacionalna reaproprijacija, a s druge kao "usaglašavanje s europskim vrijednostima", s dominantnim pravnim i političkim standardima koji se temelje na fundamentalnim pravima i slobodama građana, odnosno na liberalno-demokratskom imaginariju i republikanskim principima vladavine koji, barem na istoku Europe, imaju institucionalni oblik "(etno)nacionalne države". Države istočne i srednje Europe danas su više-manje stabilne nacionalne države, upravo liberalne demokratije unutar granica nacionalne države koja ima svog hegemonijskog etničkog - domaćinskog - referenta, počivajući na jasno uspostavljenom

1 Proces etnokulturne nacionalizacije, prema Brubakeru, sastoji se od sljedećih elemenata: "Postojanje (ili preciznije zamišljanje postojanja) 'središnje nacije' ili nacionalnosti koja je definirana u etnokulturnim terminima i oštro odijeljena od statusa građanina ili trajnog boravka podanika cijele države; 2. ideja da ta središnja nacija legitimno 'posjeduje' državu, naime da država postoji kao država za tu središnju naciju i od nje; 3. ideja da ključna nacija ne bilježi procvat, da njezini specifični interesi nisu adekvatno 'realizirani’ ili ‘izraženi' u postojećoj državi unatoč njezinom legitimnom 'posjedu' te države; 4. ideja da je potreban naročit tip djelovanja s ciljem promoviranja jezika, kulturnog procvata, demografske dominacije, ekonomskog blagostanja i političke hegemonije središnje nacije; 5. koncepcija i opravdanje takvog djelovanja shvaća se kao oporavak ili kompenzacija, potrebna da se ispravi prethodna diskriminacija kojoj je nacija bila izložena u prošlosti dok nije stekla 'svoju vlastitu' državu koja bdije i promovira njene interese; 6. mobilizacija na temelju ovih ideja u brojnim kontekstima - zakonodavna tijela, izborne kampanje, tisak, udruge, univerziteti, ulice - s ciljem da se oblikuju politike ili djelovanja države; 7. usvajanje politika i djelovanja, formalnih ili neformalnih, koji se temelje na gore istaknutim idejama od strane države, pojedinačnih državnih agencija i čimbenika te nevladinih organizacija" (Brubaker, 1996: 415-416).

2 Pojava nacionalizma tokom i poslije Baršunaste revolucije 1989. uglavnom se, blagonaklono, interpretirala kao proces desovjetizacije (Banac, 2017) u širem kontekstu "kraja svih ideologija". Namjesto epohe "bez ideologije", kako je glasio jedan od slogana Revolucije, ipak je ono što se desilo 1989. bila, kako nagovješćuje Heywood, samo zamjena jednog ideološkog sistema drugim, pri čemu je, i to je povijesna činjenica, uspostava tog novog ideološkog poretka odnijela stotinjak hiljada nedužnih života - uglavnom na području bivše Jugoslavije; u ime "nove ideologije" koja se ustanovljavala pod sloganom "kraja ideologije" počinjen je genocid, izvršeno je temeljito etničko čišćenje uz prateću, manje više-kriminalnu "redistribuciju” bogatstva koja se odvijala pod imperativom "slobodnog tržišta". 
odnosu suverene političke moći. Slom komunističkog bloka i njegova europeizacija koja je uslijedila precizno su slijedili taj dvostruki obrazac. U zemlji s nejasnim "domaćinskim" referentom kakva je, prema hegemonijskom obrascu države-nacije, $\mathrm{BiH}$, etnonacionalno se apropriraju institucije najprije na oružano zaposjednutim nacionalnim teritorijama, a potom, na državnom nivou, apropriraju se etnokratskim procedurama "mjesta moći" - ministarska, doministarska, poslanička, direktorska mjesta i slično.

Etnonacionalizam kao hegemonijski narativ i sistem praksi političkog djelovanja mogli bismo onda razumjeti kao podvrstu nacionalizma, koji je uglavnom karakterističan za političke zajednice europskog Istoka koje smatraju da nacionalna država počiva na jednoj središnjoj etnonaciji i što je moguće zanemarivijoj manjini čiji su pripadnici tek "državljani”, te da je njihovo "nacionalno pitanje" slabo ili nikako riješeno, odnosno stalno postoji razlog za unutarnja kristaliziranja i mobiliziranja nacionalnog osjećaja uslijed unutrašnjih (manjine) ili vanjskih opasnosti (susjedna država s pretenzijama, imigranti i izbjeglice ili "stalno vrebajući Bruxelles"), o čemu svjedoče i suvremena populistička previranja u Poljskoj, Slovačkoj, Mađarskoj itd. Ozbiljniji slučajevi neriješenog nacionalnog pitanja tiču se nacionalnih granica, odnosno poklapanja granica nacije-države sa zamišljenim granicama domaćinske etničke grupe s jedne strane te učvršćenog, hegemonijskog položaja "domaćinskog naroda" koji predstavlja homogenu većinu nasuprot etničkih manjina s druge strane. Etnonacionalizam je onda glavno obilježje nacionalističkih ideologija na istočnoj periferiji Europe gdje se nacionalne države zamišljaju kao politički prostor jedne etničke središnje "etnonacije" (“core nation": Brubaker) i što je moguće manje etničke manjine. Budući da počiva u neizvjesnom prostoru nedovršenosti nacionalnog projekta, ideologija nacionalne države ima prvenstvenu funkciju proizvodnje poželjne stvarnosti. Dakle, ona nije puki ornament ili tek strategija za otimanje vlasti, već, kako to definira Heywood,

manje-više koherentan skup ideja koji pruža osnovu za organizovano političko djelovanje, bez obzira na to kakav je cilj djelovanja - da očuva, modifikuje ili sruši postojeći sistem vlasti. Stoga sve ideologije: a) nude prikaz postojećeg poretka, obično u obliku "pogleda na svijet"; b) iznose model željene budućnosti, viziju "dobrog društva" i c) objašnjavaju kako može i kako bi trebalo da se izvede politička promjena - kako da se od a) stigne do b) (Heywood, 2005: 12).

\section{Mit i ideologija: $k$ političkoj ontologiji nacionaliteta}

Pa ipak, tako postavljena, ideologija nam ne objašnjava visok stupanj prihvaćenosti među građanima. Naime, brojni intelektualci, udruženja civilnog društva, specijalizirane organizacije i institucije, pa čak i inozemni politički akteri u BiH kontinuirano nude svoje prikaze postojećeg poretka, iznose svoje racionalno utemeljene vizije 
"boljeg društva", nerijetko predlažu i konkretne korake koji će nas odvesti od jednog do drugog stanja. No njima redovito izostaje široka podrška. Njihovi projekti nisu u stanju mobilizirati značajniji broj ljudi. U BiH primjer za takve perspektive je vizija BiH kao građanske države. Za takve prikaze i kontra-ideološke projekcije često će se reći da su "apstrakcije", da "nisu u dodiru sa stvarnosti", dok se dominantne ideološke projekcije uvijek nekako "osjećaju stvarnim". Ono što često ispuštamo iz vidokruga ideološkog djelovanja je afektivni moment, element osjećane stvarnosti.

Ta "prirodnost", "intuitivnost", počesto i "zdravorazumnost" hegemonijskog ideološkog dovodi ga u blizinu "mitološkog" koje je uvijek u jezgri ideološkog. Budući da je ideologija posebno zainteresirana za naturalizirajuće efekte koji joj omogućuju nesmetanu reprodukciju, za nju su mitski elementi koje proizvodi u mreži svojih diskurzivnih praksi od osobite koristi. U svojoj knjizi Rat $i$ mit Dejan Jović kaže:

Mitovi pojednostavljuju činjenice i pričaju zavodljivu, često logičnu i svakako atraktivnu priču o nama. Oni najprije konstruiraju nas kao subjekte, naše kolektivno $M i$, a potom nas predstavljaju kao heroje, žrtve, čudotvorce, pravednike, kao izabran narod koji je iz teških vremena izlazio jači, bolji, pravedniji. U procesu stalnog (re)konstruiranja nacije, a naročito nakon traumatičnih iskustava kroz koje nacija prolazi, oni predstavljaju novi oslonac, te time stvaraju dojam stabilnosti i trajnosti (Jović, 2017: 34).

Premda možemo reći da je mitotvorstvo, općenito kazano, bilo prvi odgovor čovjeka na njegovu dubinsku potrebu koju John Dewey opisuje kao “žudnju za sigurnošću", ne treba žuriti sa zaključkom da je u današnje doba vladavine racionaliteta ono mitološko prognano, odnosno da je rezervirano samo za takozvana zaostala plemena i narode, nego izgleda da prebiva, i to nam pokazuje Roland Barthes, $\mathrm{u}$ samom srcu savremenog samorazumijevanja i samim tim subjektivizacije. Ta stalna težnja ka povratku onom supstancijalnom, izvornoj uronjenosti u izvjesnu, predvidivu ritmiku prirodnog kruženja otkriva jednu vrlo važnu karakteristiku mitopoetske misli koju detektira Roland Barthes, a koja predstavlja sam smisao političkog mitologiziranja: to je karakteristika naturalizacije. Bit mita, pa tako i političkog mita jeste da "odbrani jedan sistem, ili poredak kojeg nam mitovi saopštavaju" (Kalve, 1976: 36). Ponavljanje i stalno isticanje dominantnih figura, ritualno usvajanje, rađa postupno strukturnost te predaje (mythosa) koja sobom garantira izvjesnost, garantira da je to nešto po sebi razumljivo, prirodno. U takvom postupanju dešava se prema Barthesu svojevrsno "iskrivljenje".

Kako je historijski način mišljenja svojstven racionalnom, mit upravo kroz proizvodnju vlastite strukturnosti odstranjuje ono što je historijsko iz osnovnog sistema, onog na kojem se stvara: mit, naglašava Barthes, nastaje kroz gubljenje hi- 
storičnosti stvari: stvari u mitu zaboravljaju kad su izrađene. U lažnoj suprotnosti između Prirode i Kulture... mit se predstavlja kao nešto prirodno, to jest pretvara se da se dehistorizira, da se depolitizira... postaje ono-po-sebi-razumljivo. Mit ima funkciju da iskrivljuje: on iskrivljuje historiju da bi je lakše porekao, crpi iz kulturnog da bi polagao pravo na prirodno... njegova osnovna funkcija proizlazi iz njegove forme, ali takođe iz njegovih upotreba (Barthes u ibid.: 45-46).

Mit je svakako besmislen bez aktivnog učešća primatelja, ali ne kao ravnopravnog sugovornika, već kao su-udionika u procesu naturalizacije kroz ponavljanje, ritualno učešće u mreži njegovih praksi, čime mit postaje osnovom političke ideologije jer istoj služi kao most prema "samorazumljivosti”, "prirodnosti”. Iz tog ugla gledano, "mitologija se može odrediti kao slaganje sa svetom, ali ne sa takvim kakav on jeste, već sa takvim kakav teži da postane" (ibid.: 50). U političkoj dimenziji mitološki svijet koji se kroz razgranatu mrežu ideoloških aparata proizvodi postaje svijet kakav on jeste, postaje očigledan, prirodan, na kraju jedini mogući svijet; mit se na taj način, zajedno sa ideologijom koju možemo u ovom svjetlu razumjeti kao diskurs njegovog opravdanja, naturalizira kroz usklađena djelovanja podanika političke zajednice koji slobodno prisvajaju njegove procedure i održavaju njegovu strukturnost. Taj proces naturalizacije za Barthesa nije samo nešto što može biti nazvano ideološkim iskrivljenjem, već svojevrsna krađa smisla. Mit se onda javlja, kako primjećuje Barthes, kao “depolitizirani govor”, govor prirodnosti. On ima zadatak "davanja jednoj historijskoj intenciji prirodnog opravdanja čineći da se ono kontingentno pojavi kao vječno" što ga čini, kako Barthes sugerira, "najprikladnijim instrumentom ideološke inverzije" (Barthes, 1991: 142).

Što bi mogao značiti "politički mit” i koja bi mogla biti njegova obilježja? Mitove, odnosno političke mitove Girling definira kao:

emocionalno nabijene reakcije, bilo da je riječ o emocijama frustracija zbog ili oslobođenja od specifičnih uslova. S tim u vezi, oni trebaju biti interpretirani unutar specifičnih konteksta u kojim nastaju, to jest, kritičnih perioda u povijesti određene zemlje ili zajednice. Mitovi otkrivaju različite načine na koje se ljudi nose s periodima kritične promjene. Oni služe za mobilizaciju energije naroda; daju smisao egzistenciji naroda usred svjetskih previranja; daju osjećaj solidarnosti među članovima jedne grupe - različit od osjećaja solidarnosti izvan te grupe koja se često percipira kao inferiorna ili neprijateljska (Girling, 1993: 11).

Budući da je ideologija posebno zainteresirana za naturalizirajuće efekte koji joj omogućuju nesmetanu reprodukciju, za nju su mitski elementi od osobite koristi. Kako mitsko označava bliskost čulnom, čuvstvenom, ono, može se reći, predstavlja neku vrstu mosta ka prirodnom, ka onom što se opisuje kao doticaj s osjećanom, stvarnom stvarnošću koja je, kako to Louis Althusser kaže, "takva i takva i drugačija biti ne može” (vidi Althusser, 2008). Unutar jednog takvog ideološkog projekta, 
prema Barthesu, "mit ima zadatak davanja jednoj historijskoj intenciji prirodnog opravdanja čineći da se ono kontingentno pojavi kao vječno (čitajmo tu, naprimjer, prirodnu i samim time vječnu netrpeljivost bosanskohercegovačkih naroda - op. A. M.)... mit je najprikladniji instrument za ideološku inverziju... [jer] ono što mit pruža zauzvrat jeste prirodna slika te stvarnosti... [pa je tako]... mit konstituiran gubitkom historijske kvalitete stvari" (Barthes, 1991: 142).

Barthes je posebno zainteresiran za djelovanje mita unutar dominantne buržujske nacionalističke ideologije. Mitološki elementi buržujske ideologije, prema Barthesu, za posljedicu imaju depolitizaciju govora jer se instalira "prirodni govor". Kako se odvija taj proces? Depolitizacija kao ideološka strategija vladajuće, buržujske klase, družine nositelja nacionalne svijesti, moguća je jedino ako se dominantni nacionalni poredak predstavi kao jedini mogući, normalan, naprosto prirodan poredak čovječanstva. Da bi se to postiglo, moraju biti uništeni tragovi kontingentne, društveno-historijski uslovljene političnosti, što podrazumijeva već pomenutu strategiju eksnominacije, odnosno neimenovanja vladajuće buržujske, nacionalne ili, prilagođeno vokabularu političkih elita s bivšeg srpsko-hrvatskog govornoga područja, državotvorne klase. Za razliku od, naprimjer, feudalne klase koja je sebe voljela imenovati kao plemenitu, kao nobles, time izravno uspostavljajući razliku spram ostatka stanovništva koje se na toj distinkciji moglo kasnije revolucionarno mobilizirati, buržujska klasa danas voli biti anonimna, neimenovana, osobito nakon sloma svog ideološkog, komunističkog neprijatelja. Ona je jedna od društvenih grupa u prirodnom poretku stvari u kojem "svako ide za svojim poslom", čije vrijednosti više nisu rezervirane samo za nju, već su, naprotiv, sveprisutne. Dakako, primjećuje Barthes, "kao ekonomska činjenica, buržoazija je imenovana bez ikakve poteškoće: otvoreno se zagovara kapitalizam. Kao politička činjenica, buržoazija već ima poteškoće u priznavanju svoje uloge: naprosto ne postoje 'buržujske' partije u parlamentu. A kao ideološka činjenica, ona potpuno nestaje”. Buržoazija tu izvodi "operaciju eksnominacije: buržoazija se definira kao društvena klasa koja ne želi biti imenovana... značenje istječe iz nje sve dok samo njeno ime postane bespotrebno" (ibid.: 137).

U što obično istječe to vrlo specifično značenje? Prema Barthesu, to značenje ulijeva se u ideju nacije. Nije nimalo slučajno da ono što govore eksponenti današnje vladajuće društvene grupacije u $\mathrm{BiH}$, bez obzira na njezin etnički predznak, govore ne u svoje ime, već kroz njih "govori narod": "moj narod želi...", "mome narodu je dosta..." i slično. Baš kako kaže Barthes, "buržoazija se spaja s nacijom čak i ako, da bi to postigla, mora iz nje isključiti one elemente za koje smatra da su neprihvatljivi (kao, naprimjer, komuniste)" (ibid.: 138). Baš zato što nema imenovanog centra ideološke i političke moći (premda postoji centar ekonomske moći), buržujska ideologija je neuhvatljiva, sveobuhvatna, sveprisutna. Ono buržujsko je 
sve i ništa posebno; ono je naprosto "univerzalno čovječansko", objektivacija same ljudske prirode, a ne može se protiv svoje prirode. Za Barthesa

ta anonimnost buržoazije postaje još izraženija kada se s buržujske kulture pažnja okrene k njenim deriviranim, vulgariziranim i primijenjenim formama, $\mathrm{k}$ onome što se zove javna filozofija, onome od čega se sastoji svakodnevno življenje, građanskim ceremonijalima, sekularnim običajima, ukratko k nepisanim normama ljudskih međuodnosa u buržujskom društvu. Cijela Francuska utopljena je u tu anonimnu ideologiju: naša štampa, naši filmovi, naše pozorište, naša šund literatura, naši rituali, naša pravda, naša diplomatija, naši razgovori, naše opaske o vremenu, suđenja za ubistvo, dirljivo vjenčanje, kuhanje jela o kojima maštamo, modni detalji koje nosimo, ukratko sve u svakodnevnom životu ovisi o predstavi koju buržoazija ima i čini nam se da je ima o odnosima između čovjeka i svijeta (ibid.: 139).

Ta eksnominacijska operacija sračunata da naturalizira partikularni ideološki poredak, dakle, nije ništa slučajno ni beznačajno, niti je to neka uzgredna pojava. To je, zaključuje Barthes, "buržujska ideologija sama, proces kroz koji buržoazija transformira stvarnost svijeta u sliku svijeta, historiju u prirodu" (ibid.: 140). I baš u tom ideološkom transformirajućem procesu historije u prirodu posebnu ulogu igra mit. Ta je uloga, za Barthesa, uloga ekonomičnosti. "Ona ukida kompleksnost ljudskih djelovanja, ona im daje jednostavnost, prekida svaku dijalektičnost... ona organizira svijet koji je bez kontradikcija jer je bez dubine, široko je otvoren i uvaljan u očigledno; ona etablira blaženu jasnoću" (ibid.: 143).

Marksističkim rječnikom kazano, ideološko-mitološki svijet je svijet otuđenja. Od čega se sastoji to otuđenje? U svojoj knjizi Zašto je Marx bio u pravu? Terry Eagleton kaže kako društvenu stvarnost "treba shvatiti kao rezultat našeg vlastitog djelovanja. Ako je kao takvu ne vidimo, dakle, ako je smatramo nečim prirodnim ili neizbježnim (što se upravo dešava u ideološko-mitološkom narativu - op. A. M.), neovisnim o našoj djelatnosti - onda je na djelu ono što Marx naziva otuđenjem" (Eagleton, 2011: 131). U tom smislu ideologiju bismo mogli nazvati i privilegiranom sistematičnom naracijom opravdanja otuđenja, odnosno otuđujućeg poretka društvene stvarnosti. Mit je na taj način čuvar otuđenog poretka jer je okidač njegove naturalizacije. Zato je uobičajeno, ne samo u diskursima svakodnevlja nego i u onima akademske i znanstvene prirode, o etnicitetima, koji su uz klasu, rasu i rod društvene kategorije, govoriti esencijalistički, kao o "stvarima-u-svijetu" (Brubaker, 2004). Nerijetko su se baš članovi akademske zajednice i intelektualci, društveni i politički teoretičari, ponašali u svemu tome kao prirodni znanstvenici, pa su tematici, naprimjer, bosanskohercegovačke multietnonacionalnosti pristupali kao prema trima odjelitim stvarima koje sada treba smjestiti u zadovoljavajuće odnose izbalansiranog međusobnog "magnetizma" i "repulzije" koji bi se, pod sretnim 
okolnostima, našli u podmetu svake društveno-političke građevine na tom prostoru. Takav pseudoprirodoslovni imaginarij često je kvalificiran i kvalificira se kao "realnost". Bilo kakvo propitivanje te jednoznačne percepcije etnonacionalnih datosti diskvalificira se kao napad na realnost, kao "vještačko konstruiranje" i apstrahiranje. Ako ipak napustimo taj "prirodoslovni" diskurs etnije kao stvari-u-svijetu koja ima svoje "magnetno polje", odnosno, politološki kazano, kao uniformno tijelo koje ima svoju "svijest", "svrhu" i "volju", ako posegnemo za drugim, historičnijim, kontekstualiziranijim interpretacijama, recimo za objašnjenjima jednog Ernesta Gellnera koji tvrdi "da nema nacije bez nacionalizma, odnosno da tek nacionalizam stvara naciju kao naciju" (Gellner u Sekulić, 2006: 43), onda smo na tragu toga da predodžbu o već zgotovljenom nacionalnom tijelu koje nešto želi i nekud hoće da ide zamijenimo predodžbom o aktivnoj proizvodnji nacionalnog tijela, stalnom procesu političkog subjektiviranja, živoj borbi sučeljenih, ponajprije diskurzivnih praksi koje stalno tkaju tkaninu nacionalnog, odnosno da namjesto o grupi jasnih rubova zaokruženoj u svom smislu govorimo o grupstvu, kako kaže Rogers Brubaker, naime da opisujemo što je to što radimo kada smo "nacionalni", "etnični", to jest kada smo vođeni "nacionalnim" ili "etničkim" uvjerenjima.

Temeljna karakteristika pristupa pitanju etnopolitičkog identiteta osobito u $\mathrm{BiH}$ izvire tako iz onoga što Brubaker naziva "analitičkim grupizmom". Riječ je o tendenciji da se nacije i etničke grupe tretiraju kao "supstancijalni entiteti kojima se mogu pripisivati interesi i subjektivitet" (Brubaker, 2004: 31). Vidimo da je takva tendencija uvijek već u pratnji "osjećane" stvarnosti i njezinog spekulativnog lanca opravdanja. U takvom jednom intelektualnom svijetu u kojem se "nacija' predstavlja kao prirodna, objektivna i gotovo biološka jedinica” (Blommaert i Verschueren, 1998: 199), u svijetu, dakle, kojim dominira reprezentacionalistički obrazac, iznenađujuće je lako razumijevati etnički konflikt kao nešto što se dešava između dvije ili više u sebi identitetski koherentne i odjelite grupe - npr. Srbi nasuprot Hrvata, odnosno Bošnjaka - naprosto dva ili više subjekata, na temelju čega je onda lako praviti pojednostavljujuće šeme njihovih odjelitih političkih artikulacija koje, naravno prigodno, jednoznačno artikuliraju njihove vladajuće elite. Za takav način razmišljanja, vidjeli smo, kaže se da naprosto reprezentira, odražava stvarnost jer daje govoriti tim "jedinicama realiteta", etničkim grupama kao "stvarimau-svijetu". Osim toga, ta realističnost biva pojačana vezivanjem za određeni etnički teritorij. Taj obrazac razumijevanja, već je rečeno, preovladava i u dominantnom svakodnevnom pučkom predstavljanju situacije i u političkoj i žurnalističkoj pragmatici, pa čak nije rijedak, kako sam već spomenuo, ni među članovima akademske zajednice.

Tome nasuprot stoji antireprezentacionalistički obrazac po kojemu etniciteti onda "nisu stvari-u-svijetu, već perspektive svijeta - nisu ontološki, već epistemološki realiteti" (Brubaker, 2004: 45). S tim u vezi, međuetnički sukob - nasilni ili 
politički, svejedno - dā se sada konceptualizirati ne kao konflikt između dva ili više koherentnih, u sebi zaokruženih subjekata, već kao posebna društvena interakcija koja se proizvodi kao etnička. Siniša Malešević upozorava na to da smo "kao istraživači društva, svesni da je etnicitet društveni konstrukt, ali je važno da otkrijemo zašto većina društvenih učesnika teži da ga posmatra kao "realnu stvar"' (Malešević, 2009: 139). Odgovor će se svakako naći na tragu teze da "realističnost" nekog društvenog konstrukta počiva na konkretnoj ideološkoj hegemoniji koja ga zauzvrat djelatno re-producira ponajprije kroz svoje političko djelovanje i odlučivanje, kroz mrežu svojih medija, kroz obrazovni sistem, kroz prakse administrativnog aparata i slično, iza kojih kao "garant" stoji cijela metafizika nacionalnog identiteta. Analitičnost u ovom slučaju znači istraživanje mehanizama procesa kategorizacije - etničke mobilizacije, odnosno proizvođenja i kontekstualiziranja određenih interakcija etničkim - uz istovremeno zanemarivanje brojnih drugih interakcija, generiranja društvenih konflikata i načina na koje etnopolitički poduzetnici proizvode etnički konflikt. Ako se pak upitamo, da parafraziram Judith Butler, pod kojim uslovima, diskurzivnim i institucionalnim, određene etničke razlike postaju politički relevantnima, postaju izvorom političke moći i mobilizacije, mogli bismo postaviti antireprezentacionalističku hipotezu po kojoj su to s jedne strane diskurzivni i institucionalni uslovi "nacionalne države" shvaćene kao države homogenog etnonacionalnog domaćina i zanemarive etnonacionalne manjine, a s druge strane njima komplementarni diskurzivni i institucionalni uslovi kapitalističkog poretka iz kojega se nacionalni poredak historijski izdiže, a koji podrazumijeva klasnu strukturiranost. Subjekt proizvodnje nacionalno-kapitalističkog poretka je vladajuća klasa, u slučaju BiH klasa etnopolitičkih poduzetnika (Brubaker, 2004) koja je u posjedu sredstava za proizvodnju društvenog života uopće: i materijalnog i onog simboličkog.

Taj antireprezentacionalistički obrazac konceptualizira etnicitet i nacionalnost unutar dinamike partikularne društvene kategorije "konstitutivnog naroda" - tokom devedesetih godina u regionu bivše Jugoslavije, ali i u sadašnjem bosanskohercegovačkom kontekstu ustavno-politički nametnute kao dominantne političke kategorije međusobnog priznanja građana - koja je postala i ostala esencijalnim dijelom kognitivnih mapa ili okvira putem kojih kao individue percipiramo i razumijevamo svijet. Društvene kategorije, sa svoje strane, "izražavaju određeni tip jedinstva među ljudima; one su jedno objašnjenje kako je moguće međusobno povezivanje ljudi" (Pinkard, 1986: 224), odnosno one su "izraz temeljne forme jedinstva među ljudima - strukture međusobnog priznanja” (ibid.: 225). Dok društvene kategorije općenito, kako vidimo, predstavljaju "temeljne tipove etičkih odnosa koje imamo jedni s drugima" (ibid.), u jednom etnopolitičkom kontekstu one postaju jedini politički relevantan tip jedinstva među ljudima, odnosno međusobnog priznanja, transformirajući se, kako je uostalom i samim ustavom propisano, iz tipa etničkih u temeljni, supstancijalni tip političkih odnosa. 
Politička proizvodnja etniciteta kao stvari-u-svijetu naziva se etnopolitikom, a njezino naturaliziranje ideološki je projekt. Jedina je svrha etnopolitike, barem u istočnoj i jugoistočnoj Europi, proizvodnja nacionalne države ${ }^{3}$ u kojoj će taj etnos predstavljati homogenu većinu sa što je moguće većim udjelom u ukupnom broju stanovnika države. Legitimacijski narativ te etnopolitike je ideologija etnonacionalizma kao zbirno ime za niz društvenih praksi fokusiranih oko cilja stvaranja "svoje" nacionalne države. Istočno- i jugoistočnoeuropski antikomunizam nastao je "nevjerovatnim i uglavnom implicitno retoričkim preokretom koji je definirao komunizam kao protivnika ljudske prirode", za vrijeme kojeg je suštinski "nacionalizam postao ekvivalent demokratizaciji” (Blommaert i Verschueren, 1998: 204). "Etničko" kao gravitaciono polje političkog, odnosno "etnocentrizam" već je sam po sebi, kako ističe Malešević, “oblik rudimentarne ideologije” (Malešević, 2009: 152).

Akteri proizvodnje etniciteta kao "stvari-u-svijetu" jesu političke elite koje, kako navodi Malešević, kroz "institucije države, masovne medije, obrazovni sistem... ne samo što uveliko oblikuju kolektivne percepcije stvarnosti nego ih i društveni učesnici opažaju kao stvarne entitete" (ibid.: 139). Da bi se proizveo ovaj kolektivni subjektivitet kao "stvar-u-svijetu" i kao supstancijalitet, ili kao neki zamišljeni "a priori" svake moguće interakcije u javnom prostoru, zadatak vladajuće etnopolitike je sistematsko generiranje pravila društvenog postupanja - mreže diskurzivnih praksi koje konstituiraju etničku naciju, to jest, kako to sugerira Judith Butler, generiranje "regulisanog procesa ponavljanja, koji se upravo proizvodnjom suptancijalizirajućih učinaka skriva i nameće svoja pravila" (Butler, 2010b: 292). Rezultat je fiksni etnonacionalni identitet ili, kako to Butler kaže, razumijevanje "subjekta" "kao stabilne egzistencije koja prethodi kulturnom polju kroz koje se kreće" (ibid.: 288) postajući "premisom cjelokupnog političkog silogizma" (Butler, 2010a). Althusser primjećuje da je "krajnji uslov proizvodnje reprodukcija uslova proizvodnje" (Althusser, 2008: 1). Tako se etnopolitika može razumjeti kao mreža "diskursa kojima upravljaju pravila diskursa koji upravljaju razumljivim pozivanjem na identitet” (Butler, 2010a: 291). Ta ontologija etničke grupe u ovom etnopolitičkom kontekstu funkcionira kao "normativni nalog" koji određuje i homogenizira identitet kolektiva, koji "određuje šta se kvalifikuje kao razumljiv" (ibid.: 296) etnonacionalitet i na taj način se transsupstancijalizira kao nužna osnova svakog mogućeg političkog diskursa. Usmjereni proces označavanja, ili proces označava-

3 Tako De Standaard 27. septembra 1991. u vezi s Baršunastom revolucijom piše: "Posvuda u Europi milioni ljudi vide priliku da ostvare stare snove kulturne neovisnosti, samoodređenja i državne autonomnosti. Nestanak olovnog plašta koji su komunistički režimi zastrli preko zemalja i naroda sada je oslobodio kulturne i političke sile koje su kadra iscrtati novu mapu kontinenta u desetljećima koja slijede. Davno zaboravljeni centri nemira i opasnosti izgleda da nikada nisu nestali" (u Blommaert i Verschueren, 1998: 200). 
nja kao politički projekt koji za rezultat ima proizvodnju, stvaranje, događanja naroda kao "stvari-u-svijetu", dakle kao pozitivne činjenice - drugo je ime za ideologiju. Prema Louisu Althusseru, "ideologija vladajuće klase 4 ne postaje vladajućom ideologijom milošću Božjom niti samim zauzimanjem državne moći. Ona postaje vladajuća upravo instalacijom ideoloških državnih aparata ${ }^{5}$ kroz koje se ona realizira, i to na taj način da postaje vladajućom ideologijom" (Althusser, 2008: 59). Da bi se nesmetano nastavio proces ideološke proizvodnje na razini mreže ideoloških državnih aparata, prema Althusseru, postoji njihov garant, a to je u najširem smislu represivni državni aparat, ustavno-pravni poredak koji uz postojeće instrumente brutalne sile svojim ustavnim, pravnim i institucionalnim dizajnom omogućuje i legitimira rad ideoloških državnih aparata. Na taj način dobili smo puni krug unutar kojeg ideologija funkcionira s ontologizirajućim učinkom: politički vođenim procesom ona proizvodi društvene kategorije (narod ili narode sa svojim odjelitim identitetima) i kontekste unutar kojih se oni razvijaju, sudaraju i međusobno oblikuju, a na koje se potom poziva kao na "prirodne stvari", "stvari-u-svijetu", fakticitet, činjenice, odnosno realnosti.

Politička kultura takve zatvorene konstelacije može se opisati kao statična - jer njezina ontološka dimenzija počiva izvan historije i prostora. To je država potpune vladavine etnonacionalne ideologije. To je nepokretna država jer je etnonacionalni identitet kao metafizička, dakle izvanhistorijska kategorija postao jedini centar gravitacionog političkog polja. Drugim riječima, dominacija etnonacionalističke ideologije čini izlišnim, pa čak i nemogućim bilo kakav drugi ideološki pogled. Tako su sve političke partije manje-više etnonacionalne partije; ne postoji potreba za regularnim političkim ideološkim spektrom (na što ukazuje npr. flagrantno odsustvo ljevice u Srbiji, Hrvatskoj i BiH, ukoliko se neka općenita civilno-društvenjačka agenda kao ideološki liberalno-konzervativna u svojoj biti neće smatrati ljevicom). Tako je, naprimjer, BiH kao kompleksna, pluralna, etnonacionalna država ugušila sve druge ideologije demokratskog političkog spektra, sve druge društvene konflikte osim etničkih, ukinula je historiju i vrijeme jer počiva na naturaliziranom ideološkom poretku dovršenih, sebi-dovoljnih entiteta etničkog identiteta, bili oni teritorijalni ili ne.

${ }^{4}$ U slučaju etnonacionalne BiH vladajuću klasu čine, poslužit ću se rječnikom Rogersa Brubakera, "etnopolitički poduzetnici", dakle u najširem smislu svi oni koji su interesno vezani za postojeći poredak iz koga crpe određeni stupanj osobne moći: političari, poduzetnici, intelektualci, kler i slični.

5 Ideološki državni aparati su za Althussera neke važne društvene "specijalizirane institucije", kao, naprimjer, "religijski ideološki državni aparati (IDA) (sistem različitih crkvi); obrazovni IDA (sistem različitih javnih i privatnih škola); obiteljski IDA; pravni IDA; politički IDA (politički sistem, uključujući i različite partije); sindikalni IDA; komunikacijski IDA (štampa, radio i televizija itd.); kulturni IDA (književnost, umjetnost, sport itd.)" (Althusser, 2008: 17). 


\section{Revolucionarni klasni subjektivitet branitelja vitalnog nacionalnog interesa}

Sada treba razmotriti nositelje tog kompleksnog procesa etnokulturne nacionalizacije, odnosno etnopolitičke subjektivizacije. Već duže vrijeme u društvenim naukama i općenito dominira mišljenje da je pojam "klase" "postao relativno beznačajan za moderna zapadna društva" (Giddens, 1989: 215). U "istočnim” društvima nakon "demokratske tranzicije" pojam klase je generalno odbacivan kao ostatak komunističkog hegemonijskog vokabulara. Intelektualni trend nakon Baršunaste revolucije upravo je karakteriziralo odbacivanje "klase" i uvođenje kulturnog identiteta u žižu rasprava vladajućeg etičko-političkog diskursa. Danas bi imalo smisla postaviti hipotezu da je svojevremeno odsustvo govora o klasi bilo sastavnim dijelom eksnominacijske strategije vladajuće klase u usponu s ciljem prikrivanja procesa kapitalističke reaproprijacije. Marxovo određenje klase kao društvenog odnosa vlasnika sredstava za proizvodnju i onih koji na tim sredstvima rade, odnosno "jedno od glavnih strukturalnih obilježja ljudskog društva" u vidu "njegove podjele na vladajuću ekploatatorsku grupu na jednoj strani i podređene, eksploatisane grupe na drugoj” (Botomor, 2008: 38) odbacivano je kao odveć redukcionističko, pa i esencijalističko. Možemo se, naprimjer, s Ernestom Laclauom složiti u njegovom prigovoru protiv "klasnog redukcionizma" u razumijevanju društvenih odnosa i perspektiva političkog subjektiviranja, ali, s druge strane, politički subjektivitet ne može biti isključivo diskurzivni, kulturno-identitetski konstrukt. Uostalom, na toj pretpostavci počiva cijela "posthistorijska" politika identiteta. Zato je neophodan pojam klase koji referira na mjesto koje građanin političke zajednice zauzima u proizvodnom procesu, procesu proizvodnje ukupnog duhovnog i materijalnog života te neproblematično zasijeca sve druge vitalne društvene kategorije kao što su nacija, rasa, rod i slično. Također se možemo, donekle, složiti s Laclauom da je pozni razvoj kapitalizma smanjio značaj klase za proces formiranja političkog subjektiviteta. Ali to je posljedica njene pojačane pauperizacije s jedne i ideološke redeskripcije s druge strane. Klasa, drugim riječima, nije nestala i postala prazan označitelj, već je njezin sadržaj ispunjen - ideološkim naputkom - novim terminima: rase, konfesije, etniciteta, nacije, dakle cijelom lepezom partikularizirajućih identiteta koji se u društvenom prostoru pojavljuju kao međusobno suprotstavljeni i isključujući; tako da od ovog ili onog konkretnog individualnog drveta više nismo u stanju sagledati šumu. Od identitetskog drveta nismo u stanju vidjeti klasnu šumu koja je pred nama. Baš analiza tih novih formi života koje se javljaju i naizgled čine pojam klase zastarjelim, kako opaža Oliver Harrison, "mogla bi obogatiti naše razumijevanje novih formi klasnog antagonizma danas" (Harrison, 2014: 59).

Kritičari će često ukazivati na "esencijalizam" pojma klase koji se izražava u poziciji koju čovjek zauzima u proizvodnom procesu: dakle, on je ili vlasnik (dioničar) sredstava za proizvodnju ili neko ko na njima radi. Teško je vidjeti kako se 
ta pozicioniranost može izbjeći, a još je teže ignorirati politički relevantne posljedice takve pozicioniranosti u konkretnom životu savremene društvene i političke zajednice. Jedna od neposrednih posljedica te pozicioniranosti jeste da je efektivno prva grupa ljudi "politički narod", dok su pripadnici druge grupe na različite načine - opresijom, ideologijom, kulturno-zabavnom industrijom - efektivno isključeni i međusobno fragmentirani na različite identitetske grupe koje su obuhvaćene labavim i, moramo reći, ideološkim terminom civilnog društva, od kojih svaka ponaosob traži da bude "uračunata" i "uključena". To zahtijeva, kako bi to rekla Hannah Arendt, relevantno političko pojavljivanje. Političku dinamiku države često određuju njihovi pojedinačni zahtjevi za priznanjem. Pojedinačna priznanja su karakteristika liberalne demokratije i predstavljaju "okolišni put" k potpunom priznanju svih u skladu s univerzalnim principima liberalizma i prosvjetiteljstva. Taj okolišni put može često, uslijed dinamike historijskih procesa, da krene i unazad, k novim isključenjima kakva se uvelike dešavaju nakon "nulte tačke" suvremenog doba: događajem od 11. septembra 2001. (poznatog i kao 9/11). Nedostatak tog parcijalnog pristupa je u tome da podrazumijeva omeđivanje (tj. "containment") u vidu nacionalne države, subjekta koji "daje priznanje" te koji reproducira i producira forme uključenosti i isključenosti, pa time i forme ugnjetavanja koje će se perpetuirati u svagda novim formama marginalizacije, isključenosti iz priznanja. Nacionalna država je uvijek, ne zaboravimo, država svoje vladajuće klase, svoga stvarnog političkog naroda. Sve dok je klasa kao obuhvatni pojam političkog subjektiviranja u drugom planu, borba za pojedinačna priznanja bit će osuđena na neuspjeh ili na pojedinačni/marginalni uspjeh. Naravno, brojne diskurzivne strategije se uzdižu iznad te podjele, pa je to slučaj i sa diskursom klasne borbe. Govor o klasnoj borbi ne znači da ne postoje rodne, etničke, rasne borbe. Štaviše, postojanje rodnih, etničkih, rasnih i raznih kulturno-religijskih borbi često skriva onu jedinu pravu, fundamentalnu, klasnu borbu. Kada govorimo o klasi, ključno pitanje koje nam se postavlja jeste ima li smisla govoriti o klasama i klasnoj borbi kada objašnjavamo sebi svoje mjesto u svijetu i svoj određeni položaj u njemu, odnosno da li će objašnjenje u terminima roda, rase, etniciteta, manjine biti plauzibilnije od onog prvog. Za neke svrhe sigurno da, ali za potrebe objašnjenja ugnjetavanja, potlačenosti, pa i političke krize sigurno ne.

Osobito nakon financijske krize iz 2008. i silazne putanje neoliberalnog kapitalizma postalo je nemoguće iz analiza društveno-političke zbilje isključiti momenat klase. Klasna socijalna stratifikacija, prema Giddensu, odlikuje se "većom fluidnošću nego što je imaju drugi tipovi stratifikacija"; ona je nešto što se uglavnom "postiže, a ne nešto dato", naprimjer, rođenjem; "Klase zavise od ekonomskih razlika između grupstava individua - od nejednakosti u posjedu i kontroli materijalnih resursa" (Giddens, 1989: 208-209). O čemu nam govori ta sociološka "činjenica"? 
Ona, izgleda, odgovara - naravno, u kontekstu svoga vremena - na presudno pitanje koje je u temelju svake političke zajednice od nastanka civilizacije, da parafraziram Johna Keanea, "šta kome, koliko i na osnovu čega pripada?" (vidi Keane, 2010). Ona je rezultat sasvim određene politike distribucije resursa, javnih dobara, bogatstva koja je rezultat trenutne političke hegemonije i trajna motivaciona snaga političkog angažmana uopće. "Uvijek je u srcu distribucijskog konflikta", navodi Piketty, bilo pitanje "kako će se prihod od proizvodnje podijeliti između radništva i kapitala?" (Piketty, 2014: 39). Ako je pak distribucija bogatstva u srcu političkog, onda teško da stoji prigovor o redukcionizmu Marxovog pojma "klase". Bit će prije da su "marksisti" u decenijama poslije Marxove smrti, a osobito komunistički ideolozi zemalja "realnog socijalizma" doprinijeli svojevrsnoj banalizaciji tog pojma razvijajući neumoljive "zakone" kauzaliteta i deterministički mehanizam putem kojega se društvena kompleksnost nasilno reducirala, što je po sebi osebujan primjer mitotvorstva. Chantal Mouffe upozorila je na taj mitološki "ekonomizam", odnosno na "kauzalnu vezu između strukture i nadgradnje pri čemu se ova druga gledala čisto kao mehanički odraz ekonomske baze" (Mouffe, 1979: 169). Taj vulgarni i krajnje ideologizirani pojam klase (to je, uostalom, povijest već pokazala), premda je pretendirao na "naučnost", pokazao se krajnje beskorisnim i učinio je komunističke autoritarne elite na europskom Istoku slijepima za promjene koje su uslijedile 1989. Klasa nije statična kategorija, već je živi odnos i nedvojbeno se tiče distribucije bogatstva u najširem smislu unutar jednog društva kroz njegovu povijest. S tim u vezi Piketty ističe kako je "historija distribucije bogatstva uvijek bila duboko politička i ne može biti reducirana na čisto ekonomske mehanizme. (...) Historija nejednakosti oblikovana je načinom na koji ekonomski, društveni i politički akteri shvaćaju šta je pravično, a šta nije, kao i relativnom moći tih aktera i kolektivnih izbora koji iz toga slijede" (Piketty, 2014: 20). Premda klasa nije jedino analitičko oruđe u našem pokušaju razumijevanja društvenih i političkih procesa, njezino ignoriranje i isključenje iz analiza, čemu svjedočimo od 1989., u velikoj mjeri zamagljuje njihovo razumijevanje i omogućuje, sa svoje strane, pojavu esencijalizma druge vrste - onog kulturno-identitetskog koji se pokazuje pogubnim posebno za razumijevanje etnički kompleksnog bosanskohercegovačkog tranzicijskog društva.

Ako na temelju toga sada prihvatimo da zaposjedanje države i njezinih institucija u stopu prati zaposjedanje državnih dobara, odnosno raspodjelu moći raspolaganja njezinim materijalnim resursima, sljedeće pitanje koje moramo postaviti glasi: “Ko je subjekt tog zaposjedanja?". Očito ne može biti govora o nekom spontanom, nasumičnom zaposjedanju. Subjekt tog revolucionarnog zaposjedanja, aproprijacije, nakon 1989. određujemo Brubakerovim terminom "etnopolitički poduzetnici” (Brubaker, 2004) koji se odnosi na cijelu jednu klasu koju Karel Kosik opisuje kao "lumpenburžoaziju", "koja se regrutira od obogaćenih, ali za razliku 
od normalnih, pristojnih pripadnika svoga sloja, spaja svoje poduzetništvo s mafijaštvom, podvalama, s kriminalnim podzemljem" (Kosik, 2007: 288). ${ }^{6}$ Svojom drugom nogom ta je etnopoduzetnička klasa, dakako, u politici gdje figurira kao vladajuća politička elita, ali na jedan eksnominacijski način po kojem ona vlada kao narod sam, ili njegov dio koji skrbi o vitalnom nacionalnom interesu. U tom kontekstu lakše će nam biti objasniti zbunjujuću činjenicu političkog života u $\mathrm{BiH}$, naime, da nikakve suštinske razlike nema među dominantnim partijama u $\mathrm{BiH}$ jer su sve etnopolitičke i svaka na svoj način djeluje u službi "prvobitne akumulacije kapitala" ne samo kroz razne forme procesa privatizacije, prekrajanjem privatizacijskih zakona i praksi prema svom "liku", nego i kroz raspodjelu pozicija moći i odlučivanja u javnim i političkim institucijama i preduzećima. Ideološka pozadina tih partija sažeta u formuli "etnonacionalizam plus etnokapitalizam" identična je bez obzira na njihov etnički predznak ili njegovo odsustvo. Njihovi "antikorupcioni programi”, ako ih je uopće i bilo, samo su bili brutalni suparnički razračuni s ciljem da se konkurent istisne iz procesa akumulacije kapitala ili iz političkih institucija gdje se o procesu aproprijacije može odlučivati, pri čemu se koriste svi raspoloživi (Althusserovi) državni aparati i ideološki državni aparati unutar vlastitog (još-nepodržavljenog) "etničkog korpusa" unutar kojega treba pobijediti suparničku elitu, pretendenta na moć, dobra i kapital. Interesantno je kako je etnopolitički proces "zaposjedanja", bez obzira na to što nacionalna država nije u potpunosti ostvarena, već se ostvaruje na nekom "provizornom” teritoriju u kojoj dominira jedna etnička glasačka baza, u principu identičan "zaposjedanju" i reaproprijacijskim mehanizmima u sređenijim nacionalnim državama. Takvo je zaposjedanje po svojoj formi, doduše, parcijalno - zaposjedaju se firme i institucije zatečene na očišćenom teritoriju, ministarska i doministarska, direktorska i zamjenička mjesta zagarantirana etničkim kvotama u centralnim institucijama itd. Ali suštinski, ispod fabriciranih i održavanih slika anahronosti i primordijalnosti bosanskohercegovačkog političkog života i njegovih ključnih aktera kriju se obrisi iste lumpenburžoazije kakvu

${ }^{6}$ Kosik tu re-kapitalizaciju, koja nipošto nije jednoznačan fenomen ni puka rekapitulacija već dogođene kapitalizacije kontinenta, opisuje ovako: "U češkim se zemljama danas isprepliću dva procesa: restauracija primitivnog kapitalizma 19. stoljeća i instauracija savremenog sofisticiranog neokapitalizma. Ljudi su uključeni u neprekidni diktatorski tok slikovnosti (radio, televizija, reklama, film) i pasivno konzumiraju servirane stereotipe, tako da gube maštovitost i imaginacijsku kreativnost: postali su žrtvom industrije slikovnosti” (Kosik, 2007: 19). Dakle, kada govorimo o kapitalističkoj reaproprijaciji koja se odvija unutar ponovno zadobijene nacionalne države, moramo imati na umu njezinu kompleksnost koju Kosik detektira na sljedeći način: "Da bi se afirmirao, češki kapital mora postati sastavnim dijelom, dopunskom komponentom nadnarodnog kapitala i u češkim će zemljama stoga ispunjavati njegove funkcije i njegovo poslanje...”; taj kapital "vlada danas globalno kao superkapital... sve podvrgava i sve usisava u svom nastupanju i funkcioniranju” (ibid.: 24). 
nalazimo diljem europskog Istoka. Rastko Močnik se pita: "koja je to klasa koja je privatizirala potencijale naših država. To je klasa koja nije tipično kapitalistička jer nije sposobna, a to joj nije ni cilj, da vrši produkciju. To je parazitska klasa. To je klasa koju je Andre Gunder Frank nazvao lumpenburžoazijom, a koju u sociologiji nazivaju kompradorskom buržoazijom. Ona zapravo vrši usluge za transnacionalni kapital, a usput uzima ne profit nego rentu, dohodak koji proizlazi iz njenog statusa, a ne iz produktivne upotrebe kapitala" (Močnik, 2012: 39). No, je li ipak tu riječ o pravoj klasi? S jedne strane ona zadovoljava Giddensove kriterije, a s druge strane teško je govoriti o nekoj artikuliranoj "klasnoj samosvijesti”, već prije o nekom poklapanju "vitalnih materijalnih interesa". U svakom slučaju, zadovoljit ćemo se Budenovim određenjem da je riječ "o nekoj vrsti vladajuće klase unutar koje političari, premda pripadnici različitih partija, sve lakše nalaze zajednički jezik, odnosno ujedinjuju se oko svog zajedničkog interesa, koji često nema nikakve veze s interesom ljudi koji su ih izabrali” (Buden, 2016).

Iz te perspektive, dakle perspektive koja uključuje klasnu terminologiju, vrlo je stoga pogrešno, pa se i to može ubrojati u dogme bosanskohercegovačkog političkog života, smatrati za osnovu svakodnevnih međusobnih konflikata vodećih nacionalnih stranaka da su oni izrazi milenijumske mržnje, pa čak ni to da ih vode međusobno apsolutno suprotstavljeni politički agensi. Naravno, klasni interes ne smije biti vidljiv u javnosti, on mora, kako naglašava Barthes, biti prešućen, ispušten, zbog čega često dobija svoje vidljivo beskompromisno, svadljivo nacionalističko ruho. Nacionalnim strankama, pa i onima koje nominalno to nisu, zajednički cilj je dominacija vlastitih klasnih interesa nad svim ostalim interesima u društvu. Međustranački i unutarstranački sukobi kojima obiluje bosanskohercegovačka politička scena uglavnom nastaju stoga što vladajući sloj još uvijek nije konsolidiran - previše je suparničkih, osporavateljskih frakcija koje se međusobno bore za prevlast. Te se borbe mogu opisati kao ratovi frakcija lumpenburžoazije "koje su se našle na pogrešnoj strani, bez i najmanje namjere naravno da suštinski dovedu u pitanje prirodu sistema koji je omogućio širenje tog društvenog kancera" (Mladenović, 2014: 57). Ali, sve to ne mijenja suštinsku tiraniju nad nižim slojevima građanstva. Osvrćući se na sličnu situaciju u Srbiji, Mladenović kaže:

Tokom devedesetih im je (lumpenburžoaziji - op. A. M.) odgovarala zatvorena kapitalistička država i nacionalistička histerija kako bi mogli nesmetano da grabe društvena bogatstva stvarana u socijalističkoj Jugoslaviji, da bi sada, s obzirom na njihov parazitski karakter i nesposobnost da stvaraju nova dobra, insistirali na otvorenoj tržišnoj privredi kako bi opljačkano prodali, ili u najboljem slučaju, kako bi postali direktni posrednici između srbijanskog lokalnog tržišta i krupnog zapadnog kapitala (ibid.). 
U tom smislu, političke stranke - organi lumpenburžoazije - više nalikuju, kako George Novack primjećuje, političkim korporacijama čije se djelovanje svodi u osnovi na "bezobzirnu eksproprijaciju političke moći od nižih klasa, davljenje mogućnosti njihovog neovisnog političkog djelovanja ${ }^{7}$ i njihovu još intenzivniju eksploataciju za interese dominirajuće klike" (Novack, 1993: 319). Sve te stalne političke etničke mobilizacije "svojih" naroda u biti predstavljaju faze procesa stalne eksproprijacije političke moći od nižih slojeva građanstva, pa neki autori (Gagnon, 2004) s pravom ukazuju kako je etnička mobilizacija u biti demobilizacija kojoj je cilj osigurati čistu pozornicu za borbu za hegemoniju. Sastavni dio te demobilizacije je sprečavanje artikuliranja takozvane "anacionalne", odnosno "građanske" opcije koja danas nije ništa više od jedne izuzeto heterogene, unutar sebe fragmentirane, temeljno demobilizirane perspektive. ${ }^{8}$ Dakle, specifičnim institucionalnim dizajnom u vidu etnoparlamentarne demokratije producira se i reproducira, u klasnom smislu gledano, vladajuća klasa, buržoazija ili, preciznije, lumpenburžoazija. Etnopolitički poduzetnici od Rusije do Slovenije koristili su iste mehanizme koji se

7 Za vrijeme protesta u BiH u februaru 2014. godine vlastodržačka elita je demonstrante opisala kao vandale i huligane, narkomane (čak je tom prigodom iz policije podmetnuta informacija koja je na sreću brzo demantirana, naime da je prilikom demonstracija zaplijenjeno 12 kilograma droge), a protiv pojedinaca je čak dignuta optužnica za terorizam. I JMBG protesti u junu 2013. ilustriraju Novackovu tvrdnju o sprečavanju slobodnog i neovisnog djelovanja građanstva. Tada su demonstranti opisivani kao kidnaperi, odnosno cijeli protest se opisivao kao "talačka kriza".

${ }^{8}$ Ne treba zaboraviti da je "građanska opcija" bila itekako realistična opcija u Sarajevu s početka rata 1992., što se jasno da iščitati iz Platforme Predsjedništva RBiH u ratnim uslovima iz juna 1992., a osobito u Tuzli gdje je bila djelatna i dominantna tokom cijelog rata. Šire o tuzlanskoj građanskoj politici vidjeti u Ioannis Armakolas, Politika i društvo u Tuzli od 1992. do 1995. godine (2016). Premda sistematski gušena i izlagana raznim pritiscima od etnonacionalističkih kantonalnih i entitetskih vlasti, građanska opcija do današnjeg dana preživljava u Tuzli. Također treba znati da prema odluci Arbitražnog tribunala za sporno područje Brčkog još 1999. godine formirana specifična politička jedinica distrikta funkcionira do današnjeg dana uglavnom na "građanskom principu", i k tome u dodatku treba pripomenuti da funkcionira - "milenijskim mržnjama" i "dubokoj podijeljenosti” unatoč. Na kraju, prvobitna politička opcija koja se sučelila s dominantnom komunističkom opcijom na prvim izborima 1990. u BiH, dakle opcija na temelju koje su SDA, HDZ i SDS ostvarili izbornu pobjedu, bila je "građanska opcija". U predizbornoj kampanji sve te stranke izražavale su privrženost "građanskim principima" i predstavljale se kao u biti građanske stranke. Sada je odjednom - nakon oružanog i zločinačkog ostvarenja "pogodnosti" etnički čistih prostora - ta ista opcija, barem prema riječima lidera bosanskohercegovačkog HDZ-a, opcija "islamske države". Građanska opcija primjer je demobilizacije kakvu opisuje Gagnon, čija se marginalizacija jasno očitava u dinamici diskurzivnih praksi. Njezini zagovornici su tokom prvog desetljeća 21. stoljeća uglavnom bili diskvalificirani kao utopisti, zagovaratelji apstrakcija u sukobu s realnošću, potom, tamo negdje nakon propasti "aprilskog paketa” 2006., kao "skriveni bošnjački nacionalisti” i "unitaristi”, da bi danas već "uznapredovali" do statusa islamista. 
počasno mogu nazivati "tranzicijom". Razlog zašto BiH kasni u svemu tome jeste u još uvijek nedostajućoj drugoj buržujskoj, vrlo važnoj instituciji, nacionalnoj državi, odnosno u tome što nacionalno pitanje još uvijek nije riješeno na način "nacionalne države" jednog, domaćinskog naroda. Osim toga, već kod Marxa nalazimo otvoren prostor za kompleksnije tumačenje fenomena klase. Pišući o "azijatskom društvu", ukazuje na prvobitni nedostatak privatnog vlasništva kod dominantne društvene grupe: "U ovom tipu društva dominantna grupa se ne sastoji od vlasnika sredstava za proizvodnju, već od onih koji kontroliraju državni aparat" (Bottomore, 2001: 86). Lumpenburžoazije bivših jugoslavenskih republika tako predstavljaju svojevrsnu mješavinu tog "azijatskog" tipa i euroatlantskog poduzetničkog modela karakterističnog za fazu prvobitne akumulacije kapitala. Na taj način ta grupa postaje Đilasova "nova klasa" koja sama sebi kroz državnu aparaturu stvara uslove za sticanje bilo privatne imovine bilo pozicije za raspolaganje državnom imovinom, evoluirajući postupno ka statusu klase i stvarno postajući, marksistički kazano, ključnim subjektom društvenih procesa. Jasno je da u godinama oko 1989. širom istočne Europe, pa i u zemljama bivše Jugoslavije, nije moglo biti riječi o nekoj suparničkoj klasi koja bi zbacila komunističke režime, ali su Baršunasta revolucija i demokratska tranzicija stvorile uslove za rehabilitaciju klasnog poretka, kako je nagovijestio Bottomore:

Zbacivanje komunističkih diktatura istočne Europe 1989. obavili su široki narodni pokreti... što nam ukazuje na to da je glavna podjela u zemljama državnog socijalizma bila ona između vladajuće elite posebnog tipa i onih koji su joj bili potčinjeni. Bila je to sui generis vrsta stratifikacije koja se ne može u potpunosti porediti s drugim formama stratifikacije i klasne strukture, premda s njima dijeli neke zajedničke karakteristike. Krajnji ishod tih revolucija još uvijek nije jasan, ali s obzirom na to da je ponovno uvedena kapitalistička ekonomija, pojavit će se klasni sistem sličan zapadnoeuropskom, a u nekim slučajevima već se pojavio (ibid.: 87).

Subjekt demokratskog prevrata, kako opisuje Bottomore, svakako je u BiH i njezinoj okolini, kao i na europskom Istoku bio "narodni pokret" iz koga će se najprije aproprijacijom poluga državne moći ili nekog njenog dijela (etnički separatizam), a potom i oružanom nacionalnom revolucijom (Sekulić, 2006) steći uslovi za pojavu "nove klase" (Đilas) čije će dominantno obilježje - i tu se vidi direktna sprega ekonomije i politike o kojoj piše Piketty - biti poduzetništvo, odnosno u bosanskohercegovačkom slučaju etnopolitičko poduzetništvo, a ne tek poduzetništvo koje podrazumijeva vlastiti proizvodni pogon, vlastita sredstva za proizvodnju. Ovdje koncentraciju kapitala osigurava "etnopolitičko poduzetništvo" na temelju sasvim drugačije koncepcije "sredstava za proizvodnju". Ta sredstva za proizvodnju su najprije institucije i pozicije u društveno-političkoj hijerarhiji na određenom teritoriju nad kojim se ostvarila kontrola tokom oružane nacionalne revolucije. 
Tim sredstvima za proizvodnju proizvodi se život u najširem smislu kao nacionalni život. Proizvodi se specifičan tip društvenih odnosa, interakcija, solidarnosti, fraza, interpretirajućih obrazaca, rituala, mobilizacija čiji simbolički "višak vrijednosti", kao uostalom i svaki višak vrijednosti, pripada "vlasniku": etnopolitičkom poduzetniku udruženom u etnopolitičku stranku. Simbolički višak vrijednosti predstavlja reafirmaciju revolucionarno uspostavljenog odnosa moći koji počiva na dozvoli ili, bolje reći, ovlaštenju raspolaganja društvenim bogatstvom i resursima, odnosno njegovoj distribuciji i upravljanju koje se proteže na članstvo, i formalno i neformalno, u etnopolitičkoj družini. Upravo zbog toga poduzetništvo je etnopolitičko, jer zaposjedanje pozicija upravljanja društvenim bogatstvom (ne samo onim materijalnim; tu je i nematerijalno bogatstvo - statusne, moćne upravne pozicije, poslanička mjesta koja omogućuju i materijalno bogatstvo i kontrolu procesa distribucije) tijesno je povezano sa bliskošću etnopolitici odnosno družini, klasi ili nekoj njezinoj frakciji koja osporava prednost druge frakcije u raspodjeli. Taj odnos moći, njezine neravnopravne raspoređenosti, odnosno njezine koncentracije u rukama povlaštene nekolicine podrazumijeva razvlaštenje i dominaciju nad ostatkom društva. Faza etnopolitičkog poduzetništva koja je savremena, kontekstualizirana verzija Marxove "prvobitne akumulacije kapitala" ima smisla samo ako je prijelazna faza u uspostavi funkcionalnog kapitalističkog poretka i stabilne (jedno)nacionalne države.

Simbolička proizvodnja života ili, kako Marx kaže, duhovna proizvodnja izražava se u nekoj političkoj zajednici u njenoj (etno)politici, njenim zakonima, moralu, religiji, metafizici. Ako se pak, na tragu Marxa, "ljudi i njihovi stvarni odnosi javljaju u svekolikoj ideologiji kao u nekoj camera obscura na glavu postavljeni, ovaj fenomen izvire iz njihovog istorijskog životnog procesa isto tako kao što izvrtanje predmeta na mrežnjači izvire iz njihovog neposredno fizičkog" (Marx i Engels, 1964: 22). Šta se to izvrće u etnopolitičkoj camera obscura? Bosanskohercegovački ljudi i njihovi stvarni odnosi javljaju se u svekolikoj etnopolitičkoj ideologiji kao "vitalni nacionalni interes". Marx tome u prilog kaže: "svaka nova klasa koja se postavlja na mjesto jedne druge koja je prije nje vladala, primorana je, već i radi toga da bi svoj cilj postigla, da svoj interes prikaže kao zajednički interes svih članova društva" (ibid.: 48). Eto nam uputa za odgovor na "vječito" bosanskohercegovačko političko pitanje: “šta je to vitalni nacionalni interes?". To je, dakle, interes one društvene grupe koja je zavladala prikazujući svoj interes kao zajednički interes sveg građanstva, odnosno, jer je etnopolitika, interes svih članova svoje etničke grupe. Proces proizvodnje nacionalnog života odraz je "neposredne sraslosti”, kako Marx primjećuje, "materijalnih odnosa proizvodnje s njihovom historijsko-socijalnom određenosti” (Marx u Korać, 1987: 272) koja u ideološkoj etnopolitičkoj sferi ima oblik, rekao bi Ivan Čolović, "geološke sraslosti" naroda s njegovim tlom. To je 
suština demokratske tranzicije na području bivše Jugoslavije, pa i europskog Istoka. Geološka sraslost najednom postaje temelj, podloga za kodificiranje partikularne historijsko-socijalne određenosti izražena sada u pojmovima prava i politike, to jest etnopolitike koji se predstavljaju kao univerzalni i potpuno samostalni, kao supstancijaliteti, zakriljujući u potpunosti sferu "materijalnih odnosa proizvodnje". Njene devijacije, i kada isplivaju na površinu, predstavljaju se upravo tako, kao devijacije: spram trajne pravno-političke sfere, kao "korupcijska afera" koja se može, samo ako navodno postoji politička volja, lako sankcionirati. Hegemonijski pojmovi ideologije - prava, filozofije, morala itd. - marksistički kazano predstavljaju izraz "empirijskih okova i ograda unutar kojih se kreće način proizvodnje života i s njima vezani oblik odnosa" (ibid.: 275). Empirijski okovi i ograde su rezultat "preraspodjele društvenog bogatstva", odnosno njegove aproprijacije razumljene i kodificirane kao nacionalna aproprijacija "svoje" etničke zemlje, ukratko kao "nacionalno oslobođenje". Ideološki okvir nacionalnog oslobođenja je "svoja" nacionalna država unutar koje je način proizvodnje života upravo takav, nacionalan. Međutim, suštinska karakteristika takve ideološke proizvodnje korespondira s materijalnim odnosima proizvodnje. Nacionalna aproprijacija - revolucija - kodificirana je u jeziku prava, u pojmovima naroda i narodne konstitutivnosti i samo se u tim terminima odvija proces proizvodnje života. Stoga se priča o "demokratskoj tranziciji” BiH ne može u potpunosti ispričati bez priče o njezinoj vladajućoj klasi.

Kolektivni subjektivitet - revolucionarni ili drugačiji - ne može se, kako kaže Laclau, onda uopće pojmiti bez svoje diskurzivne konstrukcije. "Za Laclaua i Mouffe kolektivni subjektivitet rezultat je artikulacijske prakse te se stvara i održava uz pomoć partikularnog diskursa" (Harrison, 2014: 46) ili, u slučaju bosanskohercegovačkog hegemonijskog političkog subjektiviteta, uz pomoć etnonacionalne ideologije, ideologije nacionalnog identiteta, ravnopravnosti, subjektivnosti, suverenosti, državotvornosti. Bosanskohercegovački hegemonijski subjektiviteti posjeduju "sredstva za proizvodnju" - ne samo ona materijalna (privatizacija) već i ona nematerijalna (procedure, institucije, diskurzivne strategije-mediji, pravni okviri, metafizička sredstva, naučna, književno-umjetnička itd.). Zajedno uzevši, to su "sredstva za proizvodnju moći", onoga "omoćujućeg", što daje "realnu" podlogu za uspostavu sasvim naročite hegemonije, bilo da je riječ o materijalnom, financijskom bogatstvu bilo o simboličkom kapitalu koji emanira moć.

Takva akumulacija kapitala u BiH i njenoj okolini nije bila ništa drugo do eksproprijacija velikih narodnih masa, neposrednih proizvođača, od sredstava za rad koja su se do tada nalazila u društvenom vlasništvu. Eksproprijaciju su obavile političke elite mladih nacionalnih država na način na koji se eksproprijacija inače obavljala kroz povijest kapitalizma - kako je već o tome pisao Marx: "najnepoštednijim vandalizmom i pod nagonom najbestidnijih, najprljavijih, najpodlijih i naj- 
gnusnijih stvari” (Marx, 1969: 1184). U BiH eksproprijacija se obavila uz pomoć nacionalne revolucije, oružanog prevrata, pa je lepeza mjera i strasti bila još bogatija u svojoj brutalnosti, bezočnom pljačkanju "okupiranih-oslobođenih" teritorija uz etničko čišćenje "neposrednih proizvođača", tada još uvijek suvlasnika imovine, masovnim ubistvima i genocidom. Ekspropriran od sredstava za rad, svoje imovine koja mu je omogućavala koliko-toliko slobodnu individualnost, radnik je pretvoren u lumpenproletera - pripadnika rezervne armije rada "na čekanju", a "za kompenzaciju" je dobio jednakost $u$ pripadanju svom narodu. Bio je to brutalan prelaz od "su-vlasništva sredstava za proizvodnju unutar instituta društvenog vlasništva" do "su-udioništva u pripadanju ovoj ili onoj naciji". To je istina bosanskohercegovačke demokratske tranzicije.

\section{LITERATURA}

Althusser, Louis. 2008. On Ideology. Verso. London i New York.

Armakolas, Ioannis. 2016. Politika i društvo u Tuzli od 1992. do 1995. godine. University Press. Sarajevo.

Banac, Ivo. 2017. Bez Hrvatske i nema nesporazuma I. Jutarnji list, Zagreb, 12. maja, str. 25.

Barthes, Roland. 1991. Mythologies. The Noonday Press. New York.

Blommaert, J. i Verschueren, J. 1998. The Role of Language in European Nationalist Ideologies, u: Schieffelin, Bambi B., Woodard, Kathryn Ann, Kroskrity, Paul V. (ur.): Language Ideologies: Practice and Theory. Oxford University Press. New York: $189-210$.

Botomor, Tomas. 2008. Elite i društvo. Mediterran Publishing. Novi Sad.

Bottomore, Tom et al. (ur.). 2001. A Dictionary of Marxist Thought. Drugo izdanje. Blackwell. Oxford.

Brubaker, Rogers. 1996. Nationalizing states in the old "New Europe" - and the new. Ethnic and Racial Studies, (19), 2, april: 411-437.

Brubaker, Rogers. 2004. Ethnicity without Groups. Harvard University Press. Cambridge, Mass. i London.

Buden, Boris. 2016. "Ljevica se mora vratiti društvenoj solidarnosti”. Intervju: Č. Višnjić i G. Borković, www.buka.com, 17. decembra 2016.

Butler, Judith. 2010a. Nevolje s rodom. Karpos. Loznica.

Butler, Judith. 2010b. “Rod kao performans”. Intervju, QT, Beograd: 151-172.

Eagleton, Terry. 2011. Zašto je Marx bio u pravu. Ljevak. Zagreb. 
Gagnon, V. P. 2004. The Myth of Ethnic War. Serbia and Croatia in the 1990. Cornell University Press. Ithaca i London.

Giddens, Anthony. 1989. Sociology. Polity Press. Oxford.

Girling, John. 1993. Myths and Politics in Western Societies. Transaction Publishers. New Brunswick i London.

Harrison, Oliver. 2014. Revolutionary Subjectivity in Post-Marxist Thought. Laclau, Negri, Badiou. Ashgate. Burlington.

Heywood, Andrew. 2005. Političke ideologije. Zavod za udžbenike i nastavna sredstva. Beograd.

Jović, Dejan. 2017. Rat i mit. Politika identiteta u suvremenoj Hrvatskoj. Fraktura. Zaprešić.

Kalve, Luj Žan. 1976. Rolan Bart. Biblioteka XX vek. Beograd.

Keane, John. 2010. The Life and Death of Democracy. Pocket Books. London, Sydney, New York, Toronto.

Korać, Veljko. 1987. Marksovo shvatanje čoveka. Naprijed. Zagreb.

Kosik, Karel. 2007. O dilemama suvremene povijesti. Razlog. Zagreb.

Malešević, Siniša. 2004. Ideologija, legitimnost i nova država. Jesenski i Turk i Reč. Zagreb i Beograd.

Malešević, Siniša. 2009. Sociologija etniciteta. Fabrika knjiga. Beograd.

Malešević, Siniša. 2017. Države-nacije i nacionalizmi. Jesenski i Turk. Zagreb.

Marx, Karl. 1969. Tajna prvobitne akumulacije, u: Talcot Parsons et al. (ur.): Teorije o društvu II. Vuk Karadžić. Beograd: 1164-1185.

Marx, Karl i Engels, Friedrich. 1964. Nemačka ideologija I. Kultura. Beograd.

Mladenović, Ivica. 2014. Vrijeme parazita. Dani, Sarajevo, 17. januara, str. 56-59.

Močnik, Rastko. 2012. Nacionalna država je uvela divlji kapitalizam. Most Radija Slobodna Europa; sugovornici Boris Buden i Rastko Močnik. Oslobođenje, Sarajevo, 31. jula, str. 38-39.

Mouffe, Chantal. 1979. Hegemony and Ideology in Gramsci, u: Chantal Mouffe (ur.): Gramsci and Marxist Theory. Routledge i Kegan Paul. London, Boston i Henley: 168-204.

Novack, George. 1993. America's Revolutionary Heritage. Pathfinder. New York.

Piketty, Thomas. 2014. Capital in the Twenty-First Century. The Belknap Press of the Harvard University Press. Cambridge, London.

Pinkard, Terry. 1986. Freedom and Social Categories in Hegel's Ethics. Philosophy and Phenomenological Research, (47), 2, decembar: 209-232.

Sekulić, Gajo. 2006. Mir i rat u Bosni i Hercegovini. Od negativnog ka pozitivnom miru. Godišnjak 2006, Fakultet političkih nauka, Sarajevo, god. 1: 19-48. 


\title{
Asim Mujkić \\ IDEOLOGY, CLASS, AND THE QUESTION OF POLITICAL SUBJECTIVIZATION IN BOSNIA AND HERZEGOVINA
}

\begin{abstract}
Summary
Author investigates the role of ideology, myth and class in understanding the complex contemporary processes of political subjectivization in Bosnia and Herzegovina. Starting from the revolutionary context from the beginning of the 1990s, which the author understands as a parallel process of national and capitalist re-appropriation, the author poses the question: which are the conditions, discursive and institutional, for specific ethnic differences to become politically relevant, to become the source of political power and mobilization. The answer is explored on the basis of the anti-representationalist hypothesis according to which, on the one hand, these are the discursive and institutional conditions of "nation-state" understood as a state of homogenous ethnonational host and negligible ethnonational minority, and, on the other hand, the discursive and institutional conditions of capitalist order from which nationalist order is historically developed presupposing its class structure. The subject of the production of national-capitalist order is the ruling class; in the case of Bosnia and Herzegovina, the class of ethnopolitical entrepreneurs which is in possession of the means of production of social life in general: both in the material and in the symbolical sense.
\end{abstract}

Keywords: Ideology, Myth, Class, Political Subjectivization, Bosnia and Herzegovina

Asim Mujkić je redovni profesor na Fakultetu političkih nauka Univerziteta u Sarajevu.

Kontakt: Asim Mujkić, Fakultet političkih nauka, Skenderija 72, 71000 Sarajevo, Bosna i Hercegovina. E-mail: asim.mujkic@fpn.unsa.ba 